\title{
THE EFFECTIVENESS OF GREEN TEA AND CELERY LEAVES IN REDUCING BLOOD PRESSURE AMONG PATIENTS WITH HYPERTENSION IN JOHO, KEDIRI, EAST JAVA
}

\author{
Eka Surya Dianda Wirantika Pratiwi'), \\ Agustin Widyowati'2), Anik Nuridayanti²) \\ 1) Bachelor Program in Nursing, School of Health Sciences \\ Ganesha Husada, Kediri, East Java \\ ${ }^{2)}$ Department in Nursing, School of Health Sciences \\ Ganesha Husada, Kediri, East Java
}

\begin{abstract}
Backgrounds: Hypertension is a degenerative disease that affects public health and is a silent killer. In Indonesia, the prevalence of hypertension based on measurement results at the age of 18 years increased from $25.8 \%$ in 2013 to $34.1 \%$ in 2018 . One of the efforts that can be done to lower blood pressure is traditional medicine using green tea and celery leaves. This study aimed to analyze the effectiveness of green tea and celery leaves in reducing blood pressure among people with hypertension.

Subjects and Method: This was a randomized controlled trial (RCT) conducted in Joho, Wates, Kediri. A total of 40 patients with hypertension were divided randomly into two groups: (1) 20 patients in the experimental group who received green tea treatment, and (2) 20 patients in the experimental group who received celery leaves treatment. The dependent variable was systolic blood pressure. The independent variables were green tea or celery leaves. The data on blood pressure ( $\mathrm{mmHg}$ ) was measured by sphygmomanometer. The mean difference between the experimental and control groups were tested by independent t-test.

Result: Mean systolic blood pressure $(\mathrm{mmHg})$ after intervention in the green tea group (Mean $=130.20 ; \mathrm{SD}=3.40$ ) was comparable with that in the celery leaves group (Mean= 128.17; $\mathrm{SD}=2.71$ ), and it was statistically non-significant $(\mathrm{p}=0.120)$.

Conclusion: The effectiveness of green tea and celery leaves is comparable in reducing systolic blood pressure among patients with hypertension.
\end{abstract}

Keywords: green tea, celery leaves, blood pressure, hypertension, patients.

\section{Correspondence:}

Eka Surya Dianda Wirantika Pratiwi. Bachelor Program in Nursing, School of Health Sciences Ganesha Husada. Jl. Soekarno Hatta Gg Budaya Cipta 2 No. 2 Kediri, East Java. Email: sesilyaloverizal@yahoo.co.id. Mobile: +6285731407499 